\title{
The Covenants of the Prophet Muhammad with the Christians of the World
}

\author{
John Andrew Morrow
}

Tacoma, WA: Angelico Press and Sophia Perennis, 2013. 442 pages.

With painstaking effort and much dedication invested in this groundbreaking work, John Andrew Morrow will surely manage to attract the attention of Islamic studies students and specialists. Not only is the topic novel, but surely the approach and method are new as well. Indeed, The Covenants of the Prophet Muhammad with the Christians of the World is a genuine call for reconsidering the relationship among the three revealed Abrahamic faiths, which 
is often viewed by some quarters with vested interests through the foggy lenses of suspicion and animosity, if not of utter aggressive hostility, especially these days. The author's arguments stem from various perspectives ranging from Islamic jurisprudence to political science, economics, sociology, ethics, and leadership studies. He defends the covenants written to various groups of Christians, be they living inside the Arabian Peninsula (the Monks of Sinai, the Christians of Najran), Persia, or the world at large, as being genuine documents emanating from Prophet Muhammad himself, who assumed the responsibility of protecting these groups and pledged that his followers would do so until the last day: "This must not be violated or altered until the hour [of the Resurrection] and the end of the world" (p. 236).

Despite the volume's relative length, its main substance is to be found in Part I, which contextualizes the genesis of these covenants. Its seven chapters (pp.1-202) deal with the Messenger's early life: his travels, marriage, and relations with the Jews of Madinah, who disappointed him by choosing to rally the Qurayshi idolaters against him. Focal light is shed on his contacts with Christians before and after the revelation, as well as on the covenants as a pledge of protection and coexistence. In chapters 2-7, the author deals systematically with the issue of the covenants' texts and authenticity by striving to refute the arguments made by skeptics. Part II (chapters 8-12) presents the texts with their various versions (both in their Arabic original, whenever available) or as they evolved through time in translation. Part III, a brief section that deals with the challenges specified by the author in terms of authority issues, the question of transmissions, the contextualization of the covenants, ends by suggesting topics for future research. Part IV includes a set of appendices that cover "Witnesses to the Covenants," "Possible Modes of Transmission," and a useful set of illustrations.

Despite being a Muslim, of which he makes no secret, Morrow insists on following a meticulously sustained stand of an academic investigator, one who presents both the pros and cons of the case as well as the Islamic and non-Islamic views. Considerable space is allotted especially to western views, such as those emanating from such skeptical authors of the likes of Patricia Crone and Michael Cook (1977), Leon Arpee (1946), and others (pp. 31, 10203 , respectively, inter alia). He airs various aspects of the argument in question before providing his own view on the subject. A substantial part of the volume is devoted to defending the authenticity as well as the genuine existence of the Prophet's covenants, despite what might have occurred to their texts in terms of additions or deletions during the course of their long existence. Never tiring of producing evidence to refute rebuttals and counterarguments, includ- 
ing those coming from systematic negators, Morrow presents here an admirable case of a persuasive arguer.

Perhaps for the sake of exhaustiveness regarding the case he proposes to make, a great deal of space is allocated to the Shi 'a perspective - beside the Sunni one - in his attempt to elucidate aspects of the covenants (see the author's frequent reference to Muhammad Baqir Majlisi [2010], Qureshi [1991], Salehi [1995], Reza Shah-Kazemi [2005], and Muhammad Husayn Tabataba'i [1977], among others). This opens a window on a scholarship that may sound esoteric to some or even "unorthodox" to others. However, despite what may be said about this specific matter, the volume, in my modest opinion, has only gained in richness, depth, and breadth by this approach. If anything, the volume is an extended hand toward all monotheists to find a common ground of understanding, to look for what unites them rather than for what creates discord among them. It is a call for a more peaceful and harmonious coexistence among believers, and certainly a call for non-Muslims (and some Muslim zealots and bigots, for that matter) to reconsider their stereotyped, narrow-minded, and parochial views of Islam. And if only for this reason, the work is timely, relevant, and much needed, especially these days, in a world that is being shaken by the horrendous acts of some selfproclaimed owners of "religious truth." Suffice it to remind such people of the Qur'an's clear message: "Had your Lord pleased, all the people of the earth would have believed in Him, one and all. Would you then force people to have faith?" (Q. 10: 99).

This is indeed the essence of the message that permeates this book, which presents Islam as a religion of peace, universal humane moral values, and accepting others in their diversity and difference. After all, one may wonder philosophy-wise, what might be the purpose of a religion if it fails to unite the disunited and put together in harmony what is plural, divergent, and even conflictual? This is certainly the message that the author wishes to transmit. If his call reaches the minds before the hearts of the targeted readership (if only a section of it) and makes them rethink their positions, then it will have achieved its expected goal.

Amar Sellam Professeur de l'Enseignement Supérieur (retired), Faculty of Arts and Sciences Mohammed the First University, Oujda, Morocco 